ENTREPRENEURSHIP AND SUSTAINABILITY ISSUES

ISSN 2345-0282 (online) http://jssidoi.org/jesi/

2021 Volume 9 Number 2 (December)

http://doi.org/10.9770/jesi.2021.9.2(27)
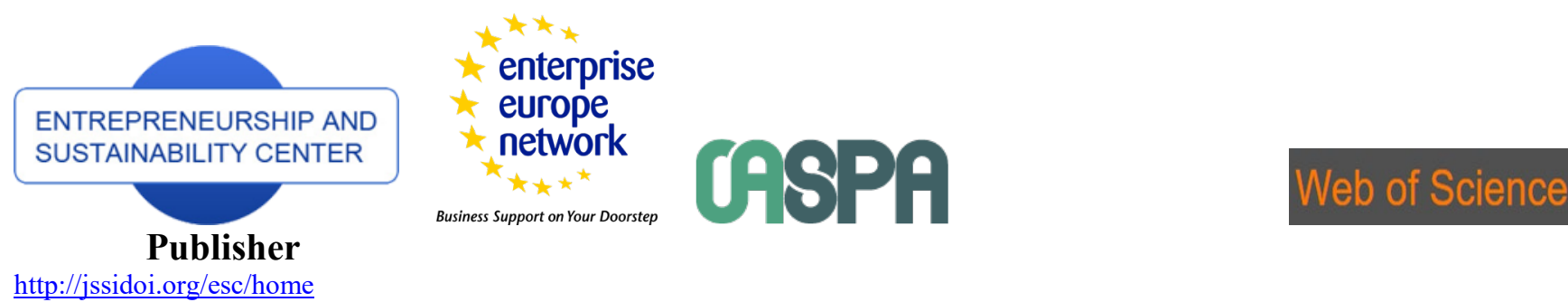

http://jssidoi.org/esc/home

\title{
FIXING A PAYOUT RATIO BY DIVIDEND POLICIES: A CASE OF THE UTILITY SECTOR
}

\author{
Marek Vochozka ${ }^{1}$, Veronika Machová ${ }^{2}$, Eliška Sedmíková ${ }^{3}$
}

\author{
1, 2,3 Institute of Technology and Business in České Budějovice, School of Expertness and Valuation, Okružni 517/10, 37001 \\ České Budějovice, Czech Republic \\ E-mails.'vochozka@mail.vstecb.cz; ${ }^{2}$ machova@mail.vstecb.cz; ${ }^{3}$ 12908@mail.vstecb.cz
}

Received 25 August 2021; accepted 10 November 2021; published 30 December 2021

\begin{abstract}
The dividend policy presents an important tool to decide whether to pay or with hold the earning. The resolute information about purchasing shares and subsequent dividends show the future prosperity of the company and its position on the market. The article aims at analysing the development of the payout ratio estimated from the current dividend policy of CEZ Company. CEZ is one of the most important suppliers and producers of electricity in the Czech Republic. The majority owner of the company is the Czech state. It can be stated that the area of operation does not only cover the Czech market, because ČEZ company also operates in other countries, mainly in Central Europe. For this reason, it is very interesting to watch the development of this power giant in terms his dominant role in a small and open economy such as the Czech Republic. The data extraction from company annual reports of 2008-2018 allows the correlation analysis to collect and interpret data on the payout ratio adequacy, examining the actual state of the company, earning distribution and corporate expectations from the market. The earning has a visibly positive impact on the payout ratio. The article offers advice for the organization changes to generalize achieved results, subsequently passing on advice for the whole segment.
\end{abstract}

Keywords: payout ratio; dividends; dividend policy; funding; earning

Reference to this paper should be made as follows: Vochozka, M., Machová, V., Sedmíková, E. 2021. Fixing a payout ratio by dividend policies: a case of the utility sector. Entrepreneurship and Sustainability Issues, 9(2), 416-432. http://doi.org/10.9770/jesi.2021.9.2(27)

JEL Classifications: B26, G15, G35, M21

\section{Introduction}

Proposing the number of dividends presents one of the most important events in capital markets in Central Europe. For ČEZ Company, this challenge involves increased activity and lengthy discussions, the reasons being, apart from others, a launched plan to build a new nuclear block in the area of Dukovany with estimated overnight price 140-150 Bill. CZK (ca 6 Bill EUR). The state as the majority owner of ČEZ, where dividends present huge earnings of the national budget, must consider that the organization is subject to substantial energetic changes caused by the wave of liberalization at the end of 1990s (Šuleř, Horák and Krulický, 2020; Iovino and Migliaccio, 2019; Rybáček, 2018). 


\section{ENTREPRENEURSHIP AND SUSTAINABILITY ISSUES}

ISSN 2345-0282 (online) http://jssidoi.org/jesi/

2021 Volume 9 Number 2 (December)

http://doi.org/10.9770/jesi.2021.9.2(27)

The cornerstone of the company dividend policy is the term 'Payout ratio', consisting of two parts. The first one tells us which part of the net profit after taxation to pay to shareholders in the form of dividends, whereas the second component informs on the amount remaining for the company after re-investments and business evaluation (Vlachý, 2018; Caha, 2017). This indicator refers to the specific dividend policy of the company.

Nowadays, we have 3 different models of dividend policies, the most common in the Czech Republic being announcing dividends according to the net income. ČEZ Company officially pursues the policy of maintaining the fixed dividend totals, thus being deeply dependent on the company net profit, with the view to avoiding potential risks incurred from wrongly choosing the payout ratio, cash-flow insolvency and failure to perform obligations. Between 2017 and 2018, the corporation followed the dividend policy of the temporary extension of the payout ratio $60 \%-100 \%$, as contrasted with former $60 \%-80 \%$, of the consolidated net income. As of 2019 , ČEZ developed the existing dividend policy from $80 \%$ to $100 \%$ of the net profit (Annual report ČEZ, 2018, 2019).

Fixing an optimum payout ratio presents an important aspect for companies. The decision is not easy to make, as enterprises must take into account two crucial elements. On the one hand, the corporation strives for exploiting available internal resources for further funding and business re-investments; on the other, it must pay owners dividends for its investments to their satisfaction.

The question is how to set the adequate amount of the payout ratio, i.e. investors' dividends. Having invested his capital, the shareholder would ideally expect the highest returns with the lowest risk and hugest liquidity. By investing in the company, he takes on the risk of losses and stock rate fluctuations from poor management, rendering the optimistic scenario impossible. The corporation is aware that choosing an inept payout ratio poses a risk, which may result in failing its obligations.

The article focuses on analysing the development of the payout ratio according to the earning of ČEZ in 20082018, concluded by professional advice not only for the given enterprise but also the entire segment of similar companies.

\section{Literature Review}

The professional literature has conducted painstaking research in paying dividends and payout ratios as an important financial indicator. The first issue is its amount, which has always been a subject of considerable discussions on corporate finance. A large number of scientists have been dealing with theoretical dividend models for a long time Jing et al. (2017), focusing on changes in the company's characteristics and the follow-up dividend development (Fama and French, 2001). Floyd et al. (2015) argue that these models describe factors playing an essential role in deciding on dividends. This resolution is crucial for company investors, as it provides feedback to the corporation to use earnings for re-investments to evaluate the enterprise, while shareholders see the importance in the earning distribution into their dividends. Grullon et al. (2002) state that changes in dividends are dependent on differences in the company's growth rate and returns on investments. Some theories on dividends suggest that dividend variations contain information on future enterprise incomes (Benartzi et al., 1997).

When investing, all investors expect maximum earnings, minimal risk and maximal liquidity. Models that play a crucial role in investors' decisions in corporate companies to protect their interests, or in the decision-making of municipal managers from the time of stability to the pandemic, can be found, for example, in the works of Kelemen et al. (2021) and Polishchuk et al. (2019). During this period, even more emphasis is placed on management in an effort to achieve profitability and avoid risk (Bacik et al., 2019; Dvorský et al., 2021). Professional experts Havlíček and Stupavský (2013) call it the investment triangle - the required income from a 


\section{ENTREPRENEURSHIP AND SUSTAINABILITY ISSUES}

ISSN 2345-0282 (online) http://jssidoi.org/jesi/

2021 Volume 9 Number 2 (December)

http://doi.org/10.9770/jesi.2021.9.2(27)

specific property, the minimal threat of not reaching the expected earnings and maximal liquidity to realize the investment at the lowest possible costs. The investor should ideally achieve all three goals, which is completely impossible. Subject to frauds, no investments meet all three requirements.

Other professionals also agree upon the basic principle of achieving only two of the three goals at a time. Kohout (2014) points out the importance of compromises, which is confirmed by Rejnuš (2014) referring to sacrificing the fulfilment of a particular objective to attain a higher, yet uncertain, future value.

On the contrary, Miller and Modigliani, pioneers to this issue, claim that when deciding upon earning distribution and follow-up dividends, the company management considers important available investment opportunities which would boost future earnings. Without making these conveniences possible, the income should go to shareholders (Miller a Modigliani, 1961).

There are several criteria to pay out or withhold dividends, the most significant being the company net profit. All incomes, irrespective of them coming from the previous or current period, need cleaning. The next factor, frequently mentioned by Gill et al. (2010) can be the corporate strategy or a phase of the company's life-cycle.

The dividend payout ratio raises a contentious issue analysed to the point of the impact on stock yields or their effects on liquidity. Ansem (2009) has recently examined the influence of the amount of dividend payout on earnings and stock price dynamics. Georgen et al. (2005) claim that changes in dividends in German companies moulded the opinion on the net income being the main reason for dividend changes. Other researchers - Tan et al. (2018) used a system of Hamilton-Jacobi-Bellman generalized equations for determining the optimal ratio, which is also highly supported by (Barth et al., 2016). Other experts, e.g. Ye et al. (2019) state that the earning plays a decisive role for paying or withholding dividends, explaining the earning rate presents a crucial factor to pay out dividends, concluding that a more profitable and liquid corporation has higher chances to pay out dividends. Gill et al. (2010) found and established an intimate connection between the dividend payout and company's earning rate, arguing that the profitability of a specific organization constitutes an essential element of the dividend payout determination on the capital market.

Fidrmuc et al. (2010) declare that components shaping the dividend policy also point in the right direction, making this specific strategy a widely discussed topic in the professional literature. The dividend payout ratio became one of the leading indicators used for analysing dividend schemes (Dragota et al., 2019). Situations when corporations do not always pay shareholders $100 \%$ earning, setting aside a certain amount to invest in company's assets, refer to the dividend policy that consists of paying a specific amount to shareholders in the form of dividends, sparing the other amount for re-investments, with the view to boosting higher future earning and shareholders' dividends.

Insider trading presents the next essential factor to determine the payout ratio. Anderson et al. (2020) and Balachandran et al. (2019) argue that companies with a higher insider trading rate have higher payout ratios than corporations owned by foreign institutions. Tran (2020) says that foreign investments negatively influence the effectiveness of national organizations on the Vietnamese market. Kim et al. (2017) analysed the same area classifying individual investors, claiming that active investors directly affect cutting down on reserves and increasing dividend payouts.

Zainudin et al. (2018) explore relations between stock price volatility and dividend policies of publicly negotiable companies in Malaysia, declaring the dividend rate reliably predicts the development of a specific stock. Kahle and Stulz (2017) spotted a rapid growth in publicly negotiable corporations on the American market within the last decade, while dividend payouts reached record values. The authors explain the trend by growing fusions, 


\section{ENTREPRENEURSHIP AND SUSTAINABILITY ISSUES}

ISSN 2345-0282 (online) http://jssidoi.org/jesi/

2021 Volume 9 Number 2 (December)

http://doi.org/10.9770/jesi.2021.9.2(27)

globalization and technological changes. Herwartz et al. (2016) present consumption growth volatility as one of the determinants long-term influencing the dividend rate.

Koussis and Makrominas (2019) examine differences between the dividend payout ratio in the US and European banks, emphasizing the importance of the risk assessment and different regulatory environment. Farooq and Ahmed (2019) reveal that the presidential election period has a deep impact on the American market when companies pay increased dividends contrary to common seasons. The next hypothesis aims at the influence of reinvestment dividend schemes in publicly negotiable corporations, analysed by Bond et al. (2019), suggesting that enterprises re-investing dividends rely less on external funding, which at the same time leads to more aggressive investments, contrary to firms paying only financial dividends.

The dividend rate and the related corporate strategy comprise a composition criterion within the evaluation index of company performance using logistic regression (Mun and Jang, 2019; Huang and Zheng, 2017). GeyerKlingberg et al. (2019) apply the dividend rate, capital costs, debt ratio and interest coverage rate to explore the heterogeneity of determinants of corporate security by meta-regression analysis. Charles, et al. (2017) focus on the effectiveness of ratio predictors such as dividend yield, dividend-price ratio and payout ratio examined on the sample of sixteen Asian-Pacific and twentyone European stock markets, concluding that however high effect their application has, their ability to predict is fairly weak. Badruzaman and Kusmayadia (2017) deal with the correlation between the payout ratio and stock prices of publicly negotiable companies, finding a direct connection between both indicators on the Indonesian market. Ernayan et al. (2017) conducted multiple regression analysis of the investment return relating to the payout ratio in the same region, revealing a profound impact on the first indicator. Evaton and Paye (2017) compare the performance of predicting the investment return on shares and alternative incomes, considering the net payout income more precise than a traditional payout ratio.

In the last decades, utility companies ranked amongst the most stable institutes on financial markets relating to dividends. This situation, however, has been changing, regarding the pursuit of climatic objectives. In fact, environmental aspects are gaining in importance (Stefko et al., 2021). A large number of researchers have been focusing on the impact of strategically cutting emissions on financial results and dividend payouts. Balachadran and Nguen (2018) argue that what plays an essential role in fixing the dividend payout ratio is the amount of emitted carbon dioxide, at the same time lowering the value of the financial results, where polluters significantly reduce the ratio and create more extensive reserves. McLaughlin et al. (2019) indicate the same problem, considering regulatory measures a principal cause of system changes in funding utility corporations in Great Britain. Wu and Kung (2020) examine lower competitiveness of utility firms focused on emission-free technologies, calling for regulatory taxation on emission machinery.

Rose and Wei (2020) evaluate the economic impacts of the Property Assessed Clean Energy (PACE) in California, exploring ecological contributions and impacts of imposed measures in terms of increased risks for the involved. Barroco and Herrera (2019) present the paradox in state-promoted investments in renewable resources in the Philippines widely used by capitalized investors (utility companies), resulting in full ownership of the utility infrastructure rather than small investors sharing the property of renewable resources.

Innovations play an important role in economic life (Gavurova et al., 2021a; Gavurova et al., 2021b), and LüdekeFreund presents business models for sustainable innovations (BMfSI) for sustainable energetics. Liu et al. (2019) emphasize the influence of regulatory models and programme support systems on reducing emissions in individual countries, arguing that occasional costs of the loss of earnings are in direct conflict with long-term environmental goals. McInerney and Bunn (2019) analyse investments in renewable and low-carbon resources by classifying utility investors, suggesting other fiscal or tax measures to make this sector more attractive, so far considered by investors as strongly dependent on political-economic decisions. 


\section{ENTREPRENEURSHIP AND SUSTAINABILITY ISSUES}

ISSN 2345-0282 (online) http://jssidoi.org/jesi/

2021 Volume 9 Number 2 (December)

http://doi.org/10.9770/jesi.2021.9.2(27)

Stede (2017) further confirms this fact by evaluating the effectiveness of stimulation-restrictive measures in Italy leading to an increase in utility and protection of the environment. He declares that there is no direct correlation between government or European encouragement and funding of utility or distribution companies. GallegoAlvarez et al. (2017) prove by linear-regression models that corporations gradually devise their strategies to be more compatible, showing social and institutional characteristics.

Li et al. (2019) reveal indirect correlation through political resources in Chinese utility enterprises, demonstrating that the stronger the political relations are, the closer the connections between political contacts and corporate performance appear. Shi (2019) uses a model of investment expectations in utility organizations within the same region to measure excessive investments and free cash flow.

Nylund et al. (2019) focus on internal and external funding of utility companies, claiming that external financing in the form of increased debt burden discourages them from innovating. Lambrecht and Myers (2017) indicate a strong aversion to taking risks and security and limited use of a tax shield, capital accumulation and other negative influences on a dynamic model of a utility corporation, considering the corporate strategic management as the crucial factor. Von Eije et al. (2017) work on the theory of Lambrecht-Myers, demonstrating regional differences where Latin American companies adjust payout ratios faster than their US counterparts. Straehl and Ibbotson (2018) reveal a remarkable correlation between GNP growth and the total payout per share (cleaned by the decline in shares from buyback), arguing that the cyclically adjusted total yield (CATY) predicts a change in the expected income, as in the cyclically adjusted price-earnings ratio (CAPE). Ning and Sobel (2018) deal with the connection between the market volatility and dividend rates, maintaining that growing endogenous values of capacities and cash coincide with the increased insecurity of the development, to which companies respond by reducing payout ratios.

Biasin et al. (2019) point out an apparent paradox phenomenon of increasing the value in companies including the earning payout in the form of investments in programmes of corporate social responsibility in terms of reviewing the company performance discussing yields on model portfolios in the sample of 50 enterprises listed on stock markets. Hsu (2018) analyses the same area, claiming that CSR (Corporate Social Responsibility) presents a functional predictor for determining the company life-cycle and, apart from other, earning management. AmorEsteban et al. (2020) examine the same sector in the area of energy companies on the example of Norsk Hydro Company, accurately assessing effects of imposed measures throughout the scope of entrepreneurship by an index of corporations using CUR matrix.

ČEZ Company provides a striking example of insider trading by an option programme for the top management available in the organization until 2019. Oded (2019) explores this area by presenting a reusable predictive model focusing on the influence of insider trading. He suggests using programmes implemented via the free market, warning about the risk of the excessively strong motivation of involved employees and related negative outcomes such as considerably low investment rates.

The dividend payout policy is a very complex issue leading to various theories explaining the payout ratio by different variables. The most frequently confirmed theories are the dividend payout ratio being dependent on the earning rate of the company, accepting the opinion that the company net income ranks amongst the main reasons to change dividends. We monitor this connection in the further steps of the specific enterprise, subsequently suggesting results for the whole segment. 


\section{Data and Methodology}

To examine the relation between profitability and payout ratio, the data obtained in the last 11 years (between 2008 and 2018) from ČEZ was used. This Czech company is active in the generation of electrical energy. Its main activity is selling electricity and providing related services. The company is dependent on the prices of electricity. If the price decreases, the earning decreases as well. Further information is available on the ČEZ web sites.

Table 1 provides information on the individual years with selected data that affects the following analysis. The data is extracted from annual reports of the given period.

Table 1. Selected data of ČEZ company (2008-2018)

\begin{tabular}{|c|c|c|c|c|}
\hline & $\begin{array}{c}\text { Net profit after taxation } \\
\text { (CZK million) }\end{array}$ & $\begin{array}{c}\text { Dividends declared } \\
\text { (CZK million) }\end{array}$ & $\begin{array}{c}\text { Number of shares } \\
\text { (millions of pieces) }\end{array}$ & $\begin{array}{c}\text { Market price of share } \\
\text { (in CZK/share) }\end{array}$ \\
\hline 2008 & 47,351 & $21,300.0$ & 538 & 784.8 \\
\hline 2009 & 51,855 & $26,700.0$ & 538 & 864.0 \\
\hline 2010 & 46,941 & $28,300.0$ & 538 & 783.0 \\
\hline 2011 & 40,753 & $26,700.0$ & 538 & 786.0 \\
\hline 2012 & 40,153 & $24,000.0$ & 538 & 680.0 \\
\hline 2013 & 35,207 & $21,400.0$ & 538 & 517.0 \\
\hline 2014 & 22,432 & $21,400.0$ & 538 & 591.0 \\
\hline 2015 & 20,547 & $21,400.0$ & 538 & 444.3 \\
\hline 2016 & 14,575 & $21,519.6$ & 538 & 430.0 \\
\hline 2017 & 18,959 & $17,753.7$ & 538 & 496.5 \\
\hline 2018 & 10,500 & $17,753.7$ & 538 & 535.0 \\
\hline
\end{tabular}

Source: Compiled by authors with data from www.cez.cz

Based on the data, an analysis of payout ratio will be carried out. According to Vochozka (2011), these are capital market indicators, which are of special importance for investors. This is supported by Růžičková (2019) claiming that these indicators are important for the following calculation, not only for the investors but also for the company itself. For the calculation of payout ratio (PR), further data is necessary, in particular the indicators of EPS and DPS. The definitions of these indicators have been modified and interpreted by the authors mentioned above.

EPS, which refers to earn per share, represents net profit per share. It is calculated as a net earning after taxation (Z) divided by the number of shares $(q a)$. It thus indicates the earning per one share. The formula is as follows:

$$
\mathrm{EPS}=\mathrm{Z} / \mathrm{qa}
$$

DPS (dividend per share) is another indicator. It represents a given dividend per one share. It is calculated as the company's declared dividends from net profit (D) divided by the number of shares $(q a)$. The formula is as follows:

$$
\mathrm{DPS}=\mathrm{D} / \mathrm{qa}
$$

The ratio of the above indicators EPS and DPS is used for the calculation of the payout ratio (PR) using the formula below. This indicator is expressed in percentage and indicates the percentage from the net earning that was divided between shareholders in the form of dividends: 


$$
P R=\frac{\frac{\mathrm{D}}{\mathrm{qa}}}{\frac{\mathrm{Z}}{\mathrm{qa}}}=\frac{\mathrm{D}}{\mathrm{qa}} \times \frac{\mathrm{Z}}{\mathrm{qa}}=\frac{\mathrm{DPS}}{\mathrm{EPS}}
$$

Another calculation using payback ratio (PB) indicates the percentage reinvested back into a company. The calculation is carried out by subtracting the payout ratio 1 :

$$
\mathrm{PB}=1-\mathrm{PR}
$$

PR and PB indicators are thus closely related, one of them expressing the share of earnings after taxation paid to shareholders, while the other expressing the share used for company's reinvestments. An important fact is that the sum of both indicators must be equal to 1 :

$$
\mathrm{PR}+\mathrm{PB}=1
$$

Another important indicator is dividend cover (DC). This indicator shows how many times the divided is covered by attributed earnings, thus indicating the use of the earning for other purposes. The calculation of DC is very simple, as it refers to the inverse value of the indicator PR, i.e.:

$$
\mathrm{DC}=\mathrm{EPS} / \mathrm{DPS}
$$

To determine the return on investment and its profitability, the ratio indicator ensures the price earnings ratio $(\mathrm{P} / \mathrm{E})$. Its value is determined by the ratio of two variables, market share price $(T a)$, which appears in the statements as the price of the share at the end of the year. This share price $(\mathrm{Ta})$ is then divided by the aforementioned earning per share (EPS):

$$
\mathrm{P} / \mathrm{E}=\mathrm{Ta} / \mathrm{EPS}
$$

The above formulas help to analyse the situation of share indicators in the company. This indicates the real situation of the company, that is, the share of the economic earning (net profit) that is allocated to dividends and the share that is used for reinvestments in the company. Using these results, it is possible to obtain further information, e.g. on how the market perceives the prospects of the company on the basis of the earnings. The indicators also enable to determine the development of the dividend depending on the earning for the recent years. The analysis results will be presented by means of a table and figures and interpreted subsequently. It is clear that a shareholder's view is not sufficient. It is necessary to connect the management, with the shareholders, who require the highest amount of dividends possible. Therefore, it is necessary to find the optimum. Using the results obtained, it needs to be assessed whether the company divides the payout ratio well or not on the basis of the earning. There must not be loss on the side of the management nor on the other side - shareholders. For the proper evaluation of both parties, correlation analysis will be used.

Using correlation $r$ it is possible to identify and prove the mutual dependence of two variables. According to Momber et al. (2017) it is so-called Pearson correlation coefficient, defined as a quotient of covariance (cov) and a product of standard deviations $(\sigma)$ : 


$$
r=\frac{\operatorname{cov}(x, y)}{\sigma_{x}{ }^{*} \sigma_{y}}
$$

In further detail:

$$
\mathrm{r}=\frac{\sum\left(\mathrm{x}_{\mathrm{i}}-\overline{\mathrm{x}}\right)^{*}\left(\mathrm{y}_{\mathrm{i}}-\overline{\mathrm{y}}\right)}{\sqrt{\sum\left(\mathrm{x}_{\mathrm{i}}-\overline{\mathrm{x}}\right)^{2} * \sum\left(\mathrm{y}_{\mathrm{i}}-\overline{\mathrm{y}}\right)^{2}}}
$$

It is an expression of the strength of the relationship between two variables, in this case, the retained earnings from the previous year and the earnings in the current year. The strength of the relationship can take values between -1 and +1 . The closer it is to one of the above values, the strong the linear correlation is.

It is generally acknowledged that there are various levels of the correlation strength, as Momber believes. Fu also mentions the levels of correlation with various values (Fu et al., 2020) When searching for these levels, it is necessary to divide the values of correlation and to determine its limit values. By connecting the limits determined by Momber et al. (2017) and Fu et al. (2020), four basic types of correlation level are achieved, which can be described verbally (see Table 2).

Table 2. Values of correlation " $r$ "

\begin{tabular}{|c|c|}
\hline Weak correlation & $\mathrm{r} \leq 0.39$ \\
\hline Moderate correlation & $\mathrm{r}=0.40-0.69$ \\
\hline Strong correlation & $\mathrm{r}=0.70-0.90$ \\
\hline Very strong correlation & $\mathrm{r} \geq 0.90$ \\
\hline
\end{tabular}

Source: Authors

This analysis enables to assess the relationship between the retained earnings of the previous year and the earnings in the current year. In conclusion, it is possible to identify whether the ratio is adequate or not, and to propose changes a company in such a situation shall adopt. Considering the results of the correlation analysis, recommendations for the whole segment can be made, specifically the recommendation on how to determine the payout ratio in other companies.

\section{Results and Discussion}

In order to examine the relationship of the indicators, the analysis of a given company's annual statements needs to be carried out. From the statements, the data for the years 2008-2019 will be extracted to analyse the effect on the payout ratio and others. Table 3 shows the calculated values of the ratio indicators in order to determine the overall situation of a company to analyse the payout ratio influenced by earnings. 
ENTREPRENEURSHIP AND SUSTAINABILITY ISSUES

ISSN 2345-0282 (online) http://jssidoi.org/jesi/ 2021 Volume 9 Number 2 (December) http://doi.org/10.9770/jesi.2021.9.2(27)

Table 3. Ratio indicators

\begin{tabular}{|c|c|c|c|c|c|c|}
\hline & EPS (CZK/share) & DPS (CZK/share) & PR (\%) & PB (\%) & DC (\%) & P / E \\
\hline 2008 & 88.0 & 40 & 45.46 & 54.54 & 220.00 & 8.92 \\
\hline 2009 & 96.4 & 50 & 51.87 & 48.13 & 192.80 & 8.96 \\
\hline 2010 & 87.3 & 53 & 60.71 & 39.29 & 164.72 & 8.97 \\
\hline 2011 & 75.7 & 50 & 66.05 & 33.95 & 151.40 & 10.38 \\
\hline 2012 & 74.6 & 45 & 60.32 & 39.68 & 165.78 & 9.12 \\
\hline 2013 & 65.4 & 40 & 61.16 & 38.84 & 163.50 & 7.91 \\
\hline 2014 & 41.7 & 40 & 95.92 & 4.08 & 104.25 & 14.17 \\
\hline 2015 & 38.2 & 40 & 104.71 & -4.71 & 95.50 & 11.63 \\
\hline 2016 & 27.1 & 40 & 147.60 & -47.60 & 67.75 & 15.87 \\
\hline 2017 & 35.2 & 33 & 93.75 & 6.25 & 106.67 & 14.11 \\
\hline 2018 & 19.5 & 33 & 169.23 & -69.23 & 59.09 & 27.44 \\
\hline
\end{tabular}

Source: Authors

It follows from the table that EPS (earnings per share) decreases in the last years due to the decrease in the overall company earnings.

The development of the dividends paid as a function of earnings for the last 11 years seems to be stable, which is confirmed by the general evaluation of energy companies in terms of dividends as one of stable sectors (Romero, 2017).

However, there was a significant decrease in the last two years, which can be disturbing for investors. The payment of DPS in 2018 was CZK 33/share from the 2017 earnings, which is $169.23 \%$ of the profit per share, which was CZK 19.5. The situation was the same in 2016, when the profit per share was CZK 35.2. Figure 1 shows the declining trend of the dividends paid. The reason for this unfavourable development is the prices on the energy stock exchange. These are the prices of electricity ČEZ profitability depends on.

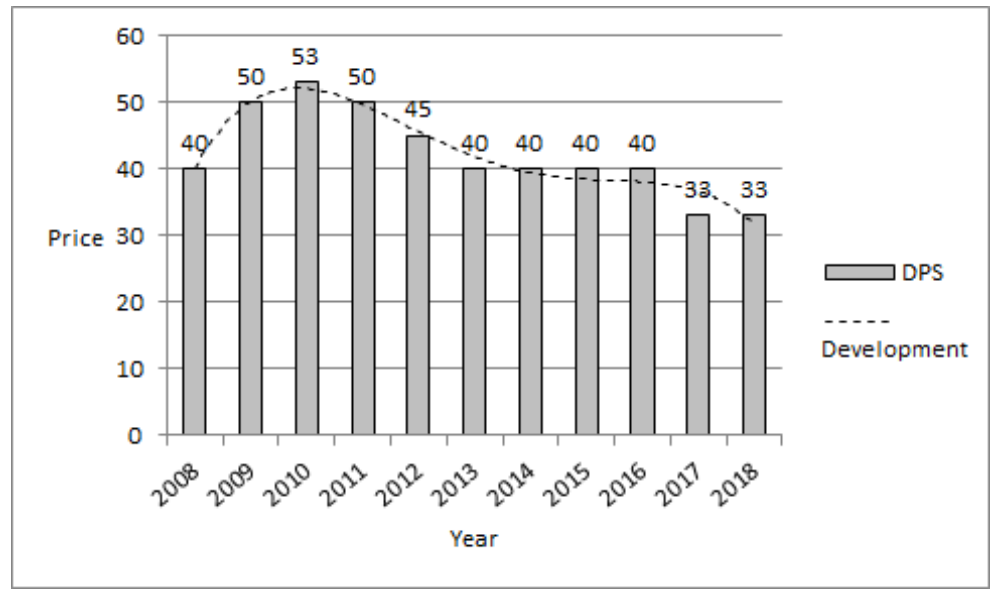

Figure 1. Development of ČEZ dividend (in CZK)

Source: Authors

A company's payout ratio (PR) is a method to measure the sustainability of the dividend flow. A lower ratio indicates sustaining more of its income for reinvestment and growth of the company, while a higher PR, in the 


\section{ENTREPRENEURSHIP AND SUSTAINABILITY ISSUES}

ISSN 2345-0282 (online) http://jssidoi.org/jesi/ 2021 Volume 9 Number 2 (December) http://doi.org/10.9770/jesi.2021.9.2(27)

case of paying more than $100 \%$, means paying the dividends exceeding the company's net income. The company thus draws from the retained earnings from the past years to pay out higher dividends. In recent years, ČEZ has been implementing a dividend policy, where the payout ratio has been temporarily expanded compared to the past years. This was also the reason for paying higher dividends to the investors and for the reduction of reinvestments in the company. This situation, when more money is paid than received does not seem to be sustainable in the long run, which is also evident from the correlation with the general trend, when energy companies in many European countries adapt their business models to the changes of the market conditions (Salm and Wüstenhagen, 2018). On the other hand, the company shows relatively low level of indebtedness and makes profit from advance sale of key commodities in the medium term. Another factor distinguishing ČEZ from the other companies operating in the energy market is a complex supply and demand vertical and relatively invested wide portfolio of production resources, where nuclear power plants play a major role. These appear to be a key price stabilization factor even to the value of the company's shares. According to Jiménez-Rodríguez (2019) in Europe, there is a clear relationship between the price of emission allowances and the price of large energy companies' shares, where emission-free resources significantly increase the value of the company.

On the basis of the monitored payback ratio (PB), it can be concluded that the reinvestments in the company have been reduced significantly in the last 5 years.

The company's prospects using the market price ratio indicator $\mathrm{P} / \mathrm{E}$ can be formulated as positive. This indicator is influenced by share price and the profit. In the current monitored situation, the $\mathrm{P} / \mathrm{E}$ value rises. Generally, it is believed that the higher the value of $\mathrm{P} / \mathrm{E}$ indicator, the more positive the evaluation. However, in the last year, the value significantly exceeded 15 . Why 15 ? In the case of investments, it is generally recommended to buys shares with the P/E lower than 15; it is a long-term average of the $\mathrm{P} / \mathrm{E}$ index $\mathrm{S} \& \mathrm{P} 500$. It means that on average, a company with this index has 15 times higher value to the profit per share. For example, in the initial year of the research (in 2008), the company had a $\mathrm{P} / \mathrm{E}$ of 8.92. This means that the buyers are willing to pay almost 9 times higher price for a share than the yearly profit is. Furthermore, this value can be seen as a return on investment; in this case, the investment will return in less than 9 years.

In the current situation, when the world is dominated by chaos and panic from the spread of COVID-19, the development of the financial market seems unclear. Due to the declaration of the state of emergency in the Czech Republic on 12 March 2020, Prague Stock Market weakened. There was noted the biggest drop since the economic crisis in 2008. According to the Czech Press Agency (CPA), almost all issues of Prague Stock Exchange fell into the red. This applies also to the shares of the energy company ČEZ, which fell by $11.27 \%$ in one day. The price at the end of the previous day was CZK 420.40, while on the following day, on 12 March, it was CZK 373. Here can be seen a specific decrease by $11.27 \%$. According to CPA, it has been the biggest decrease in ČEZ share prices in the last 4 years. Given the situation, the development of ČEZ share prices improves and starts to achieve the original values. However, it is premature to expect further positive development of the market, as the situation remains unclear.

Table 4 shows the relationship between the retained earnings of the previous year and the net profit in the current year. On the basis of the results achieved by means of correlation analysis, it can be determined whether an adequate payout ratio has or has not been set. 
ENTREPRENEURSHIP AND SUSTAINABILITY ISSUES

ISSN 2345-0282 (online) http://jssidoi.org/jesi/

2021 Volume 9 Number 2 (December)

http://doi.org/10.9770/jesi.2021.9.2(27)

Table 4. Correlation analysis

\begin{tabular}{|c|c|c|}
\hline Year & $\begin{array}{c}\text { Net profit of current year } \\
\text { (CZK million) }\end{array}$ & Retained earnings of previous year (CZK million) \\
\hline 2008 & 47,351 & 9.951 \\
\hline 2009 & 51,855 & 20.458 \\
\hline 2010 & 46,941 & 16.887 \\
\hline 2011 & 40,753 & 7.836 \\
\hline 2012 & 40,153 & 13.102 \\
\hline 2013 & 35,207 & 13.790 \\
\hline 2014 & 22,432 & 4.828 \\
\hline 2015 & 20,547 & 0.609334 \\
\hline 2016 & 14,575 & 6.595 \\
\hline 2017 & 18,959 & 8.919 \\
\hline 2018 & 10,500 & 12.648 \\
\hline \multicolumn{2}{|c|}{ Correlation coefficient $=\mathbf{0 . 6 0 7 2 1 8}$} \\
\hline
\end{tabular}

Source: Authors

The purpose of the correlation analysis is to determine the relationship between the two variables. The values of the given earnings were used for the determination of the correlation coefficient by means of Pearson formula. The strength of the relationship (0.607218) can be considered adequate. It is a moderate correlation close to 1 and thus closer to stronger correlation. The positive linear correlation thus shows moderate to strong relationship between two variables. The positive value of 0.607218 indicates direct correlation, which means that the values of the second variable increase with the increase of the values of the first variable.

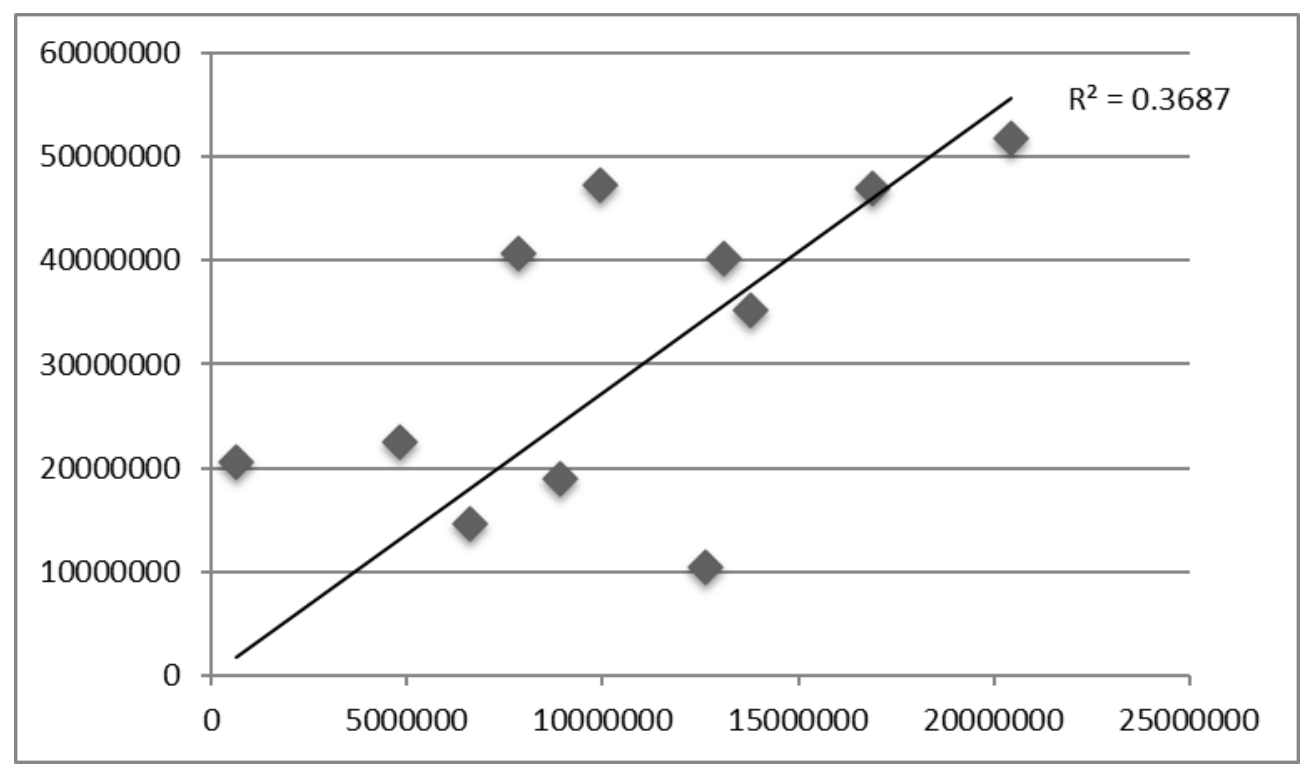

Figure 2. Positive correlation

Source: Authors 


\section{ENTREPRENEURSHIP AND SUSTAINABILITY ISSUES}

ISSN 2345-0282 (online) http://jssidoi.org/jesi/

2021 Volume 9 Number 2 (December)

http://doi.org/10.9770/jesi.2021.9.2(27)

It follows from this research that profit influences the payout ratio in a positive way. If the profit increase, the correlation coefficient will get closer to 1 and thus to almost perfect correlation. This means that the closer the relationship between the two given variables, the closer the coefficient is to 1 . The positive correlation is shown in Figure 2.

\section{Conclusions}

ČEZ is the biggest player in the market, with good economic results, stable, expanding to Europe. Czech market is open and anyone can choose; it can be said that this company is a leader in its segment. As all industries, the energy sector has also been affected by economic and financial crisis since 2008. However, its effect did not affected ČEZ significantly, since it showed high earnings even during this crisis. ČEZ owes its success to a good business policy. It sells a substantial part of its electricity production to trading companies for 2 years in advance. The permanently good economic results allow ČEZ to improve its dividend policy. Compared to previous years, when the payout ratio was 50-60\%, the company has reached a new payout limit since 2017 , which was $60-100 \%$ of the net profit. According to ČEZ's semi-annual report, a further adjustment of the payout ratio is planned for 2019. The adjustment will consist in increasing the lower limit of the payout ratio interval, the new ratio reaching $80-100 \%$ of the net profit. The main reason is the change in the strategy of the business concept and the assumption of the non-existence of the investments in renewable resources abroad. After five years of a steady economic decline, a radical change is expected for the year 2019. Thanks to better financial results and prospects for the future, better conditions for dividend payment are being created. The main reason for these results will be the rising prices of electricity the company ensures by pre-selling a part of electricity for 2 years in advance. ČEZ has and in the coming years will have better conditions for the payment of the 2019 dividend than it had in the period of 2016-2018. Thanks to pre-selling its product, even the COVID-19 crisis will not affect it significantly. Although the share prices fell to the minimum in the last 4 years during the declared state of emergency, they are currently rising back to their previous or even higher value.

The objective of this article was to analyse the development of payout ratio and its determination on the basis of the given development of the company's earnings. This objective was achieved. By means of examining the relationship of the given indicators and their subsequent analysis, the actual situation of the company, the distribution of a part of the earnings, and the prospects of the company in the market were identified on the basis of the earnings of the company. For a complex determination of whether the payout ratio is or is not adequate, correlation analysis was used, specifically, Pearson correlation coefficient, which ensured the adequate strength of the relationship, thus confirming its correct level. On this basis, it was possible to conclude that the profit has a positive effect on payout ratio. This applies to energy companies only. A prerequisite for the application of this model is the existence of the linear relationship and dependence of two variables, which refers to the profits in the given dividend policy in this case.

Adequate payout ratio requires the existence of the correlation coefficient close to 1 and a close relationship between the variables. This ensures that the values of one variable rise or decline depending on the other variable. In statistics, it is not possible to rely on one calculation only. For further determination of the payout ratio, other scientific and statistical methods can be used. Pearson correlation coefficient would be complemented by the confidence interval, which would provide the information on the variability of this estimate. This way it would be possible to further construct a confidence interval or test zero hypotheses. The sample data range should be sufficient in size for statistical methods. In addition to statistics, it is also necessary to include the knowledge of this issue in the resulting interpretation, so that it is possible to connect the results with the practical part of the context. 


\section{ENTREPRENEURSHIP AND SUSTAINABILITY ISSUES}

ISSN 2345-0282 (online) http://jssidoi.org/jesi/

2021 Volume 9 Number 2 (December)

http://doi.org/10.9770/jesi.2021.9.2(27)

\section{References}

Amor-Esteban, V., Galindo-Villardón, M., \& García-Sánchez, I. (2020). Bias in composite indexes of CSR practice: An analysis of CUR matrix decomposition. Corporate Social Responsibility and Environmental Management, 27 (4), 1914-1936. https://doi.org/10.1002/csr.1936

Anderson, W., Bhattacharyya, N., Morrill, C., \& Roberts, H. (2020). Dividend payout and executive compensation: theory and evidence from New Zealand. Accounting \& Finance, 60 (S1), 1007-1022. https://doi.org/10.1111/acfi.12399

Ansem, E. (2009). Dividends and price momentum. Journal of Banking and Finance, 33 (3), $486-494$. https://doi.org/10.1016/j.jbankfin.2008.09.004

Bacik, R., Fedorko, R., Abbas, E. W., Rigelsky, M., Ivankova, V., \& Obsatnikova, K. (2019). The impact of selected quality management attributes on the profitability of TOP hotels in the Visegrad group countries. Polish Journal of Management Studies, 19 (1), $46-58$. https://doi.org/10.17512/pjms.2019.19.1.04

Badruzaman, J., \& Kusmayadia, D. (2017). Dividend payout ratio influence towards stock price. ASIA International Conference (AIC) on Emerging Issues in Economics and Finance (EIEF) and Future of Marketing and Management (FMM). Retrieved 14 October, 2021, from: https://www.ingentaconnect.com/content/asp/asl/2017/00000023/00000009/art00146;jsessionid=1n655o4cfclsi.x-ic-live-01

Balachandran, B., \& Nguyen, J. (2018). Does carbon risk matter in firm dividend policy? Evidence from a quasi-natural experiment in an imputation environment. Journal of Banking \& Finance, 96, 249-267. https://doi.org/10.1016/i.jbankfin.2018.09.015

Balachandran, B., Khan, A., Mather, P., \& Theobald, M. (2019). Insider ownership and dividend policy in an imputation tax environment. Journal of Corporate Finance, 54, 153-167. https://doi.org/10.1016/j.jbankfin.2018.09.015

Barroco, J., \& Herrera, M. (2019). Clearing barriers to project finance for renewable energy in developing countries: A Philippines case study. Energy Policy. https://doi.org/10.1016/j.enpol.2019.111008

Barth, A., Moreno-Bromberg, S., \& Reichmann, O. (2016). A Non-stationary model of dividend distribution in a stochastic interest-rate setting. Computational Economics, 47 (3), 447-472. https://doi.org/10.1007/s10614-015-9502-y

Benartzi, S., Michaely, R., \& Thaler, R. (1997). Do changes in dividends signal the future or the past? Journal of Finance, 52, $1007-1034$. https://doi.org/10.1111/j.1540-6261.1997.tb02723.x

Biasin, M., Cerqueti, R., Giacomini, E., Marinelli, N., Quaranta, A. G., \& Riccetti, L. (2019). Macro asset allocation with social impact investments. Sustainability, 11 (11). https://doi.org/10.3390/su11113140

Bond, S. A., Pai, Y., Wang, P., \& Zheng, S. (2019). The impact of dividend reinvestment plans on firm payout choices-evidence from real estate investment trusts. Real Estate Economics, 47 (1), 178-213. https://doi.org/10.1111/1540-6229.12248

Caha, Z. (2017). Exploitation of external financial resources for corporate training purposes in the Czech Republic. Littera Scripta, 10 (1), 10-21. Retrieved October 13, 2021, from: https://ittera-scripta.com/exploitation-of-external-financial-resources-for-corporate-trainingpurposes-in-the-czech-republic/

Charles, A., Darné, O., \& Kim, J. H. (2017). International stock return predictability: evidence from new statistical tests. 5th International Conference of the Financial-Engineering-and-Banking-Society. Retrieved 14 October, 2021, from: https://www.sciencedirect.com/science/article/abs/pii/S1057521916300904?via\%3Dihub

Dragota, V., Pele, D. T., \& Yaseen, H. (2019). Dividend payout ratio follows a Tweedie distribution: International evidence. Economics EJournal, 13. https://doi.org/10.5018/economics-ejournal.ja.2019-45

Dvorsky, J., Belas, J., Gavurova, B., \& Brabenec, T. (2021) Business risk management in the context of small and medium-sized enterprises. Economic Research-Ekonomska Istraživanja, 34 (1), 1690-1708. https://doi.org/10.1080/1331677X.2020.1844588

Eaton, G., \& Paye, S. (2017). Payout yields and stock return predictability: how important is the measure of cash flow? Journal of Financial and Quantitative Analysis, 52 (4), 1639-1666. https://doi.org/10.1017/S0022109017000370 


\section{ENTREPRENEURSHIP AND SUSTAINABILITY ISSUES}

ISSN 2345-0282 (online) http://jssidoi.org/jesi/ 2021 Volume 9 Number 2 (December) http://doi.org/10.9770/jesi.2021.9.2(27)

Ernayani, R., Sari, O., \& Robiyanto, R. (2017). The effect of return on investment, cash ratio, and debt to total assets towards dividend payout ratio (A study towards manufacturing companies listed in Indonesia stock exchange). 2nd International Research Conference on Business and Economics (IRCBE). Retrieved 14 October, 2021, https://www.ingentaconnect.com/content/asp/asl/2017/00000023/00000008/art00047

Fama, E. F., \& French, K. R. (2001). Disappearing dividends: changing firm characteristics or lower propensity to pay? Journal of Financial Economics, 60 (1), 3-43. https://doi.org/10.7208/9780226426983-030

Farooq, O., (2019). Aktaruzzaman, K. Financial centers and dividend policy: evidence from an emerging market. Management Decision, 58 (6). https://doi.org/10.1108/MD-12-2017-1230

Fidrmuc, J. P., \& Jacob, M. (2010). Culture, agency cost and dividends. Journal of Comparative Economics, 38 (3), $321-339$. https://doi.org/10.1016/j.jce.2010.04.002

Floyd, N., Li, S., \& Douglas, J. (2015). Payout policy through the financial crisis: the growth of repurchases and the resilience of dividends. Journal of Financial Economics, 118 (2), 299-316. https://doi.org/10.1016/j.jfineco.2015.08.002

Fu, T., Tang, X. B., Cai, Z. K., Zuo, Y., Tang, Y. M., \& Zhao, X. H. (2020). Correlation research of phase angle variation and coating performance by means of Pearson's correlation coefficient. Progress in Organic Coatings, 139. https://doi.org/10.1016/i.porgcoat.2019.105459

Gallego-Alvarez, I., Ortas, E., Vicente-Villardón, J., \& Álvarez Etxeberria, I. (2017). Institutional constraints, stakeholder pressure and corporate environmental reporting policies. Business Strategy and the Environment, 26 (6), 807-825. https://doi.org/10.1002/bse.1952

Gavurova, B., Belas, J., Zvarikova, K., Rigelsky, M., \& Ivankova, V. (2021a). The effect of education and R\&D on tourism spending in OECD countries: An empirical study. Amfiteatru Economic, 23 (58), 806-823. https://doi.org/10.24818/EA/2021/58/806

Gavurova, B., Belas, J., Valaskova, K., Rigelsky, M., \& Ivankova, V. (2021b). Relations between infrastructure innovations and tourism spending in developed countries: A macroeconomic perspective. Technological and Economic Development of Economy, 27 (5), $1072-$ 1094. https://doi.org/10.3846/tede.2021.15361

Georgen, M., Silva, L., \& Renneboog, L. (2005). When do German firms change their dividends? Journal of Corporate Finance, 11 (2), 375-399. https://doi.org/10.1016/j.jcorpfin.2003.09.001

Geyer-Klingeberg, J., Hang, M., \& Rathgeber, A. W. (2019). What drives financial hedging? A meta-regression analysis of corporate hedging determinants. Symposium on Meta-Analysis and Systematic Reviews in International Finance. Retrieved 14 October, 2021 , from: https://www.sciencedirect.com/science/article/abs/pii/S1057521918300681?via\%3Dihub

Gill, A., Biger, N., \& Tirbewala, R. (2010). Determinants of dividend payout ratios: evidence from United States. The Open Business Journal, 3, 8-14. https://doi.org/10.2174/1874915101003010008

Grullon, G., Michaely, R., \& Swaminthan, B. (2002). Are dividend changes a sign of firm maturity? Journal of Business, 75, $387-424$. https://doi.org/10.1086/339889

Havlíček, D., \& Stupavský, M. (2013). Investor 21 stoleti [21st century investor]. Prague: Plot.

Herwartz, H., Rengel, M., \& Xu, F. (2016). Local trends in price-to-dividend ratios-assessment, predictive value, and determinants. Journal of Money, Credit and Banking, 48 (8), 1655-1690. https://doi.org/10.1111/jmcb.12370

Hsu, F. J. (2018). Does corporate social responsibility extend firm life-cycles? Management Decision, 56 (11), $2408-2436$. https://doi.org/10.1108/MD-09-2017-0865

Huang, X., \& Zheng, J. (2017). Research into the impact of analysts forecasts on management earnings forecasts - evidence from China. Littera Scripta, 10 (1), 35-49. Retrieved October 13, 2021, from: https://littera-scripta.com/research-into-the-impact-of-analysts-forecastson-management-earnings-forecasts-evidence-from-china/

Iovino, F., \& Migliaccio, G. (2019). Energy companies and sizes: an opportunity? Some empirical evidences. Energy Policy, 128, $431-439$. https://doi.org/10.1016/j.enpol.2019.01.027 


\section{ENTREPRENEURSHIP AND SUSTAINABILITY ISSUES}

ISSN 2345-0282 (online) http://jssidoi.org/jesi/

2021 Volume 9 Number 2 (December)

http://doi.org/10.9770/jesi.2021.9.2(27)

Jiang, F., Ma, Y., \& Shi, B. (2017). Stock liquidity and dividend payouts. Journal of Corporate Finance, 42, $295-314$. https://doi.org/10.1016/j.jcorpfin.2016.12.005

Jiménez-Rodríguez, R. (2019). What happens to the relationship between EU allowances prices and stock market indices in Europe? Energy Economics, 81, 13-24. https://doi.org/10.1016/j.eneco.2019.03.002

Kahle, K. M., \& Stulz, R. M. (2017). Is the US public corporation in trouble? Journal of Economic Perspectives, 31 (3), 67-88. https://doi.org/10.1257/jep.31.3.67

Kelemen, M., Polishchuk, V., Gavurova, B., Rozenberg, R., Bartok, J., Gaál, L., Gera, M., \& Kelemen, M., Jr. 2021. Model of evaluation and selection of expert group members for smart cities, green transportation and mobility: from safe times to pandemic times. Mathematics, 9, 1287. https://doi.org/10.3390/math9111287

Kim, W., Sung, T., \& Wei, S. (2017). The diffusion of corporate governance to emerging markets: evaluating two dimensions of investor heterogeneity. Journal of International Money and Finance, 70, 406-432. https://doi.org/10.1016/j.jimonfin.2016.10.002

Kohout, P. (2014). Investiční strategie pro třetí tisiciletí [Investment strategies for the third millennium]. Prague: Grada.

Koussis, N., \& Makrominas, M. (2019). What factors determine dividend smoothing by US and EU banks? Journal of Business Finance \& Accounting, 46 (7-8), 1030-1059. https://doi.org/10.1111/jbfa.12399

Lambrecht, B. M., \& Myers, M. S. (2017). The dynamics of investment, payout and debt. The Review of Financial Studies, 30 (11), $3759-$ 3800. https://doi.org/10.1093/rfs/hhx081

Li, M., Sun, X., Wang, Y., \& Song-Turner, H. (2019). The impact of political connections on the efficiency of China's renewable energy firms. Energy Economics, 83, 467-474. https://doi.org/10.1016/j.eneco.2019.06.014

Mcinerney, C., \& Bunn, D. W. (2019). Expansion of the investor base for the energy transition. Energy Policy, 129, $1240-1244$. https://doi.org/10.1016/i.enpol.2019.03.035

Liu, J., Zhang, L., Cai, J., \& Davenport. J. (2019). Legal systems, national governance and renewable energy investment: evidence from around the world. British Journal of Management, 32 (3), 1467-8551. https://doi.org/10.1111/1467-8551.12377

Mclaughlin, C., Elamer, A. A., Glen, T., Alhares, A., \& Gaber, A. (2019). Accounting society's acceptability of carbon taxes: Expectations and reality. Energy Policy, 131, 302-311. https://doi.org/10.1016/j.enpol.2019.05.008

Miller, M. H., \& Modigliani, F. (1961). Dividend policy, growth and the valuation of share. Journal of Business, 34 (4), $411-433$. Retrieved 14 October, 2021, from: https://www.jstor.org/stable/2351143

Momber, A. W. S., Buchbach, P., Plagemenn, T., \& Marquardt, T. (2017). Edge coverage of organic coatings and corrosion protection over edges under simulated ballast water tank conditions. Progress in Ogranic Coatings, 108, 90-92. https://doi.org/10.1016/j.porgcoat.2017.03.016

Mun, S. G., \& Jang. S. (2019). Indicating restaurant firms' financial constraints: a new composite index. International Journal of Contemporary Hospitality Management, 31 (4), 2014-2031. https://doi.org/10.1108/IJCHM-06-2018-0466

Ning, J., \& Sobel, M. J. (2018). Production and capacity management with internal financing. Manufacturing \& Service Operations Management, 20 (1), 147-160. https://doi.org/10.1287/msom.2017.0655

Nylund, P. A., Arimany-Serrat, N., Ferras-Hernandez, X., Viardot, E., Boateng, H., \& Brem, A. (2019). Internal and external financing of innovation sectoral differences in a longitudinal study of European firms. European Journal of Innovation Management, 23 (2), $200-213$. https://doi.org/10.1108/EJIM-09-2018-0207

Oded, J. (2019). Payout policy, financial flexibility, and agency costs of free cash flow. Journal of Business Finance \& Accounting, 47 (12), 218-252. https://doi.org/10.1111/jbfa.12407

Polishchuk, V., Kelemen, M., \& Kozuba, J. 2019. Technology improving safety of crowdfunding platforms functioning in the context of the protection of the start-up investors in the financial and transport sectors. Journal of KONBiN, 49 (1), 313330. https://doi.org/10.2478/jok-2019-0016 


\section{ENTREPRENEURSHIP AND SUSTAINABILITY ISSUES}

ISSN 2345-0282 (online) http://jssidoi.org/jesi/

2021 Volume 9 Number 2 (December)

http://doi.org/10.9770/jesi.2021.9.2(27)

Rejnuš, O. (2014). Finanční trhy [Financial markets]. Prague: Grada.

Romero, F. P. (2017). How the rivals reacted? An empirical analysis on the impact of dividend announcements on the rival firms' stock valuation. 2nd International Research Conference on Business and Economics (IRCBE). Retrieved 14 October, 2021, from: https://www.ingentaconnect.com/content/asp/asl/2017/00000023/00000008/art00146

Rose, A., \& Wei, D. (2020). Impacts of the Property Assessed Clean Energy (PACE) program on the economy of California. Energy Policy, 137. https://doi.org/10.1016/j.enpol.2019.111087

Růžičková, P. (2019). Finanční analýza. Metody, ukazatele, využití v praxi [Financial analysis. Methods, indicators, use in practice]. Prague: Grada Publishing.

Rybáček, V. (2018). The size of government in empirical research: a case study from the Czech Republic. Littera Scripta, 11 (2), $141-154$. Retrieved October 13, 2021, from: https:/littera-scripta.com/the-size-of-government-in-empirical-research-a-case-study-from-the-czechrepublic/

Salm, S., \& Wüstenhagen, R. (2018). Dream team or strange bedfellows? Complementarities and differences between incumbent energy companies and institutional investors in Swiss hydropower. Energy Policy, 121, 476-487. https://doi.org/10.1016/j.enpol.2018.04.046

Shi, M. (2019). Overinvestment and corporate governance in energy listed companies: evidence from China. Finance Research Letters, 30, 436-445. https://doi.org/10.1016/j.frl.2019.05.017

Stede, J. (2017). Bridging the industrial energy efficiency gap - Assessing the evidence from the Italian white certificate scheme. Energy Policy, 104, 112-123. https://doi.org/10.1016/j.enpol.2017.01.031

Stefko, R., Gavurova, B., Kelemen, M., Rigelsky, M., \& Ivankova, V. (2021). Relationships between renewable energy and the prevalence of morbidity in the countries of the European Union: A panel regression approach. International Journal of Environmental Research and Public Health, 18 (12), 6548. https://doi.org/10.3390/ijerph18126548

Straehl, P. U., \& Ibbotson, R. B. (2018). The long-run drivers of stock returns: total payouts and the real economy. Financial Analysts Journal, 73 (3), 32-52. https://doi.org/10.2469/faj.v73.n3.4

Šuleř, P., Horák, J., \& Krulický, T. (2020). Validation of the prediction of ČEZ stock prices. Littera Scripta, 13 (1), 194-210. https://doi.org/10.36708/Littera Scripta2020/1/13

Tan, S., Jin, Z., \& Yin, G. (2018). Optimal dividend payment strategies with debt constraint in a hybrid regime-switching jump-diffusion model. Nonlinear Analysis: Hybrid Systems, 27, 141-156. http://doi.org/10.1016/j.nahs.2017.08.007

Tran, Q. T. (2020). Foreign ownership and investment efficiency: new evidence from an emerging market. International Journal of Emerging Markets, 15 (6), 1185-1199. https://doi.org/10.1108/IJOEM-07-2019-0573

Vlachý, J. (2018). Applying the options framework to a value-based model of the firm. Littera Scripta, 11 (2), 69-79. Retrieved October 13, 2021, from: https://littera-scripta.com/applying-the-options-framework-to-a-value-based-model-of-the-firm/

Vochozka, M. (2011). Metody komplexniho hodnoceni podniku [Methods of comprehensive evaluation of the company]. Prague: Grada Publishing.

Voneije, H., Goyal, K., \& Muckley, C. B. (2017). Flexible firm-level dividends in Latin America. Finance Research Letters, 23, $133-136$. https://doi.org/10.1016/j.frl.2017.02.012

Wu, T., \& Kung, Ch. (2020). Carbon emissions, technology upgradation and financing risk of the green supply chain competition. Technological Forecasting and Social Change, 152. https://doi.org/10.1016/j.techfore.2019.119884

Ye, D., Deng, J., Liu, Y., Szewczyk, S., \& Chen, X. (2019). Does board gender diversity increase dividend payouts? Analysis of global evidence. Journal of Corporate Finance, 58, 1-26. https://doi.org/10.1016/j.jcorpfin.2019.04.002

Zainudin, R., Mahdzan, N. S., \& Yet, Ch. H. (2018). Dividend policy and stock price volatility of industrial products firms in Malaysia. International Journal of Emerging Markets, 13 (1), 203-217. https://doi.org/10.1108/IJoEM-09-2016-0250 


\section{ENTREPRENEURSHIP AND SUSTAINABILITY ISSUES}

ISSN 2345-0282 (online) http://jssidoi.org/jesi/

2021 Volume 9 Number 2 (December)

http://doi.org/10.9770/jesi.2021.9.2(27)

Marek VOCHOZKA is the professor at School of Expertness and Valuation, Institute of Technology and Business in České Budějovice, Okružní 517/10, 37001 České Budějovice (Czech Republic). Research interests: macroeconomics, microeconomics, corporate finance.

ORCID ID: $\underline{\text { https://orcid.org/ 0000-0001-9923-7814 }}$

Veronika MACHOVÁ is the researcher at School of Expertness and Valuation, Institute of Technology and Business in České Budějovice, Okružní 517/10, 37001 České Budějovice (Czech Republic). Research interests: macroeconomics, corporate finance, public policy.

ORCID ID: $\underline{\text { https://orcid.org/0000-0001-5479-6655 }}$

Eliška SEDMÍKOVÁ is a student at School of Expertness and Valuation, Institute of Technology and Business in České Budějovice, Okružní 517/10, 37001 České Budějovice (Czech Republic). Research interests: valuation, corporate finance, macroeconomics

ORCID ID: https://orcid.org/0000-0002-6910-8226

Make your research more visible, join the Twitter account of ENTREPRENEURSHIP AND SUSTAINABILITY ISSUES: @)Entrepr69728810

Copyright (C) 2021 by author(s) and VsI Entrepreneurship and Sustainability Center

This work is licensed under the Creative Commons Attribution International License (CC BY).

http://creativecommons.org/licenses/by/4.0/

(c) (i) Open Access 